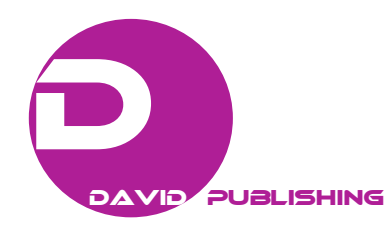

\title{
Historic Environment and Cultural Sensitivity: Ottoman Neighborhood in Macedonia
}

\author{
Belma Alik and Nevnihal Erdogan \\ Department of Architecture and Design, Kocaeli University, Kocaeli 41300, Turkey
}

\begin{abstract}
The territory of the Republic of Macedonia is divided to geographical regions, in which different types of monuments and houses from Ottoman character can be found. The monuments and regions presented through this paper do not cover all the regions of Macedonia but only the territories of Skopje, the capital of Macedonia and Ohrid. This paper involves a research of Ottoman housing and settlements in Macedonia according to the architectural characteristics and settlement textures using old-new photographs, related literature, internet sources and site investigation. The rich vernacular traditions we inherited from Ottoman ancestors would be a source for inspiring the architects in establishing the guiding principles for new buildings in Macedonia. Finally, this study concludes with some ways forward on how to attain cultural continuity for achieving sustainable development in the long run.
\end{abstract}

Key words: Historic environment, Ottoman housing, Ottoman monuments, cultural sensitivity, Macedonia.

\section{Introduction}

Macedonia (Македонија) (Fig. 1) is an ancient, biblical land, geographically located in the central part of the Balkan Peninsula. Throughout history, many important events have intertwined on the territories of the Republic of Macedonia, part Balkan, part Mediterranean and rich in Greek, Roman and Ottoman history. It offers impressive ancient sites side by side with buzzing modernity, managing to pack in much more activity and natural beauty than would seem possible for a country in this size. Ottoman rule, which lasted five centuries, takes an important part of the history of Macedonia, and with its rich Turkish culture, it has left significant marks that reflect Macedonian culture. This study will be researched in order to analyze and study the Ottoman culture in Macedonia and architectural monuments in order to preserve cultural continuity.

During the Ottoman rule in Macedonia, Skopje and Manastir (Bitola) have been capitals of separate Ottoman provinces (eyalets). The valley of the River

Corresponding author: Belma Alik, M.Sc., research fields: architecture and design.
Vardar, which has been later to become the central area of the Republic of Macedonia, has been ruled by the Ottoman Empire prior to the First Balkan War of 1912, with the exception of the brief period in 1878 when it has been liberated from Ottoman rule after the Russo-Turkish War (1877 1878).

We investigated three possible mechanisms to explain the preserved architecture in Macedonia from the 19th to 20th century: literature, old-new photographs and internet sources.

\section{Case Study 1: Skopje}

Hundreds of years of Ottoman domination have left Skopje with a distinct oriental feel and look, and many monuments from this period are remained. Unlike the darkness of the medieval Byzantine times, the Ottoman Empire has brought narcotic scent of the Orient. Due to the presence of Islamic buildings, the old part known as the Old Bazaar has got an oriental shape in the late middle ages (Fig. 2). These buildings suffered from the earthquake in 1555 , the great fire from the Austrian general Piccolomini in 1689, as well as the fire in Skopje in 1910 and the disastrous earthquake in 1963 [1]. 


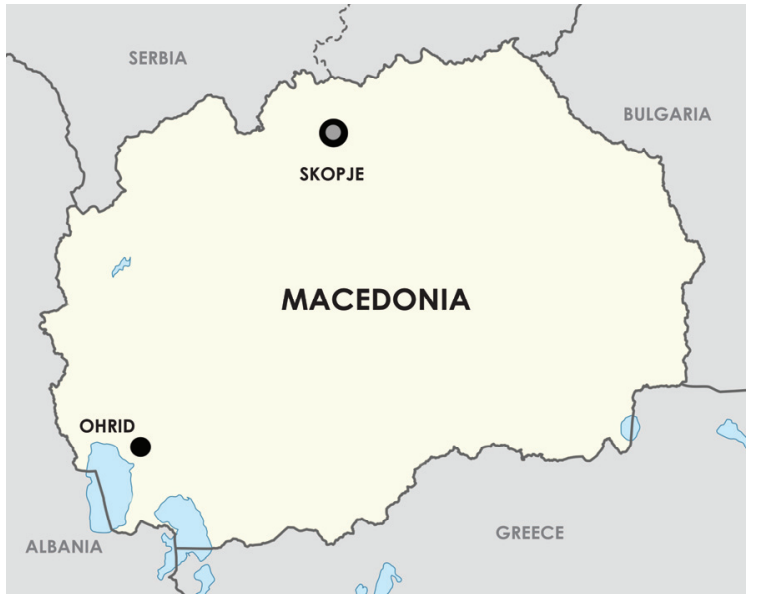

Fig. 1 Map of Macedonia.

\subsection{Old Town}

The old town of Skopje has been developed according to the oriental urban principles into two separate zones: the first zone comprised the Bazaar as a center of crafts, trade and traffic, and the second zone included neighborhoods as residential area. The merchants stores have been developed in the city center and could be approached from all sides, while residential neighborhoods were developed in a separate area, away from the business noise, protected from the street and with spacious gardens and rich interior setting [1].

\subsection{Old Bazaar in Skopje}

Under the Kale Fortress (Fig. 3) lays Skopje Old Bazaar, one of the oldest and biggest bazaars on the Balkans dating from the beginning of 12th century. Bazaar has been located in the central part of the city which gravitated to all roads. To its composition, public facilities were built for the needs of the population, bezisten, mosques, inns, caravan palaces, baths, seminaries, etc. The Old Bazaar is the type of oriental Balkan bazaars and falls into one of the largest in Macedonia. The old town streets had a distinctive look because the shops were built next to each other on an equal height as to be under one roof.

At the heart of the Bazaar has been the bezisten (covered bazaar) built from solid material that has served the needs of the guild. For easier communication

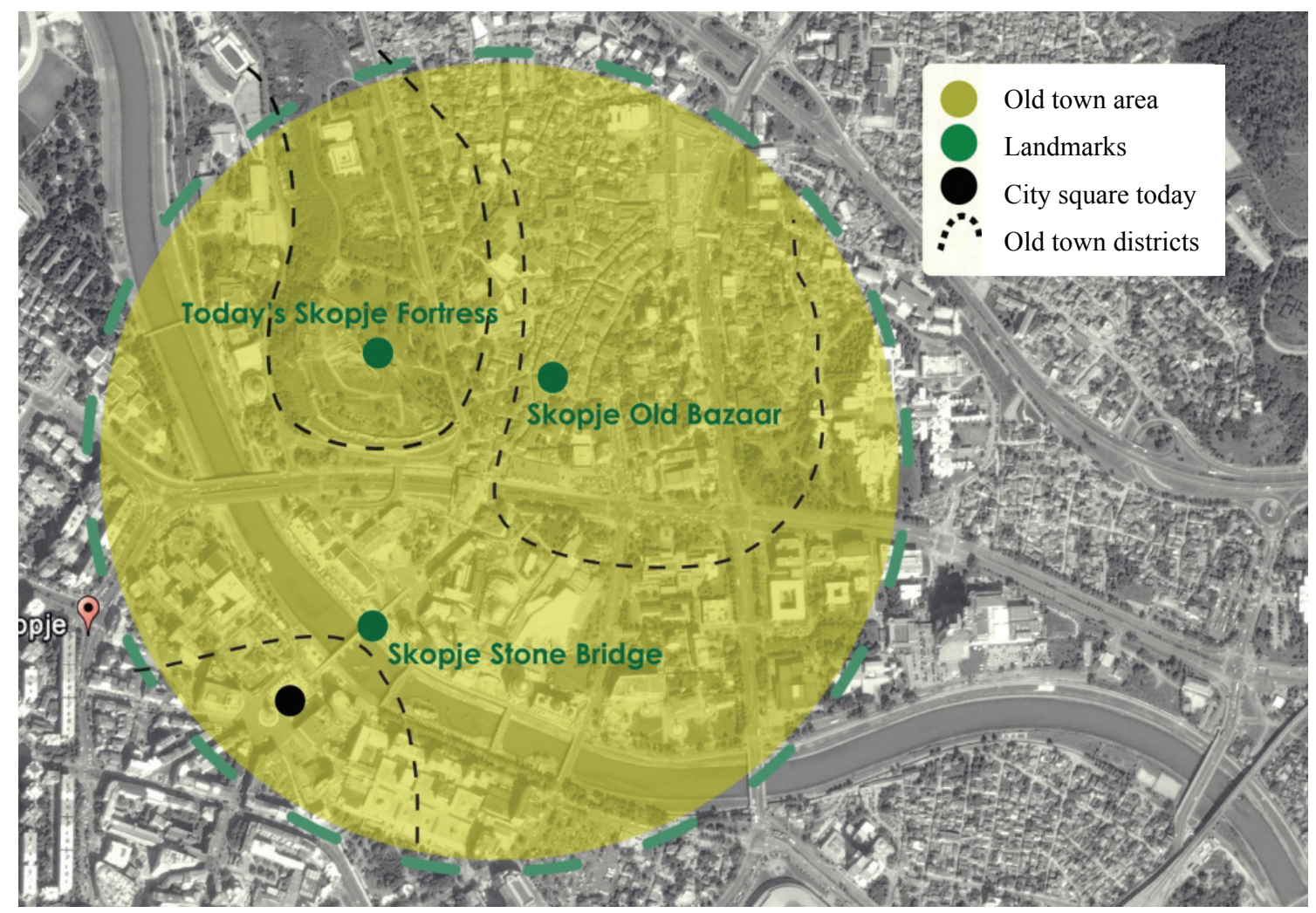

Fig. 2 Skopje old town zone. 


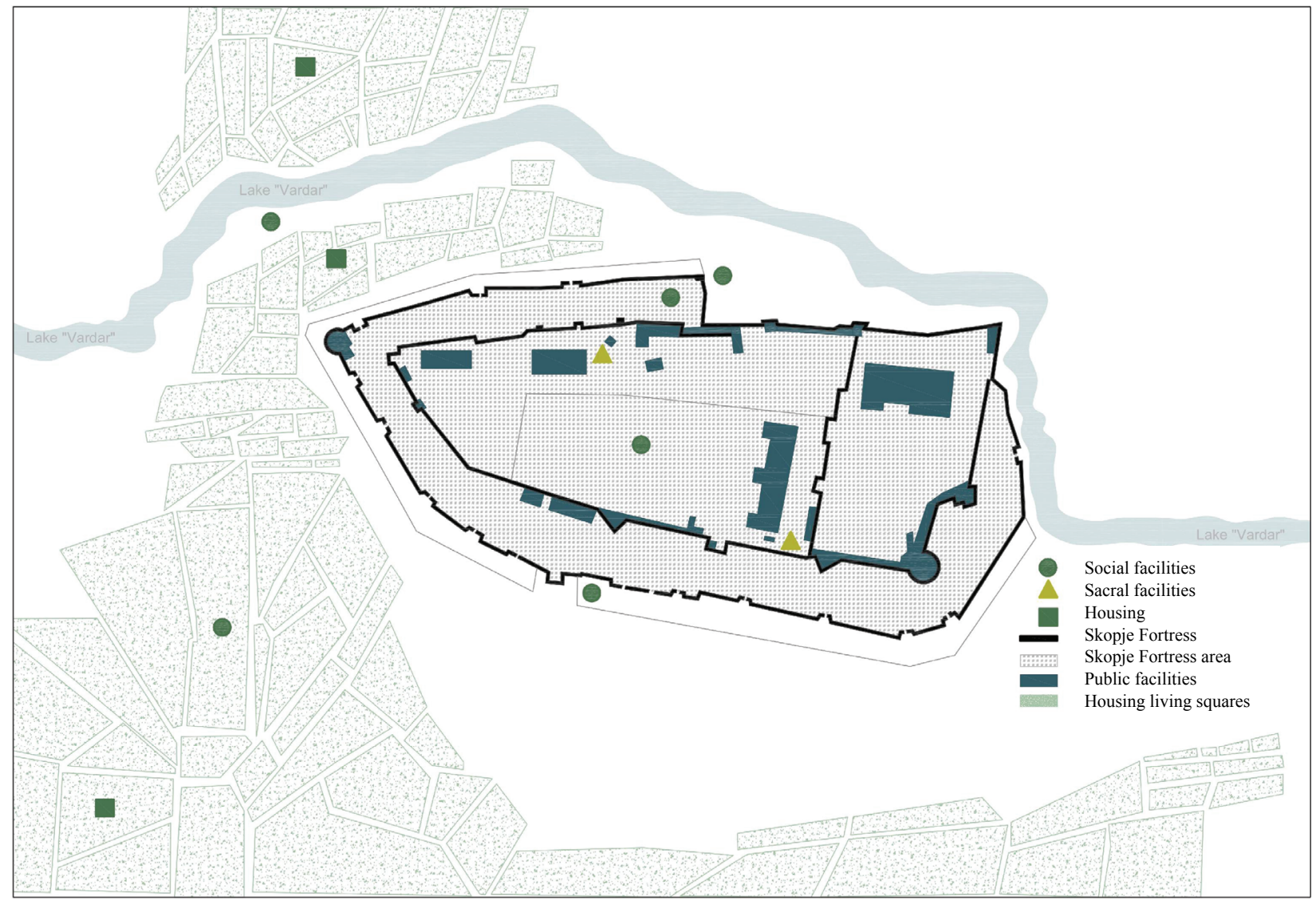

Fig. 3 The old town Fortress [2].

with the main busy streets, smaller crossings were made, on whose sides were shifted trade and craft shops that were made with simple, bandruch structures and weak material. Facades facing the street have had large openings, which were closed with lid boards.

Many of the historic buildings of the Bazaar have been transformed into museums and galleries. It is, however, still home to several active mosques, shrines, two churches and the Clock Tower, together with the buildings of the Museum of Macedonia and the Museum of Modern Art, form the core of the modern Bazaar.

\subsection{Public Monumental Artifacts in Skopje}

The subjugation of Macedonia under Ottoman authority both had hindered the development of architecture and encouraged it to adapt to the requirements of Islam and Ottoman urban life. The church has been replaced by the mosque as the centre of religious architecture. Fortified towns have given way to open settlements where the inn, the Turkish bath (hamam) and the mosque, concentrated as a group of public monumental artifacts, have became a typical characteristic of the Ottoman urban planning (Fig. 4). These buildings became the central point of a bazaar; With the addition of a Bezisten (a domed marketplace) and covered markets, as typified by Arab markets, the inn, hamam, mosque and bezisten became the pivot of urban life. This has been the greatest influence of Ottoman architecture on Macedonian architects during Ottoman rule [3].

\subsubsection{Isa Bey Mosque in Skopje}

Near the Old Bazaar (Fig. 5a), it is located the Isa Bey Mosque (Fig. 5b). It has been raised by Isa Bey, who is the founder of Alaca (Sharena-colorful) Mosque (Fig. 5c) in 1475. Unlike the others, Isa Bey Mosque is an interesting building which has two domes, 


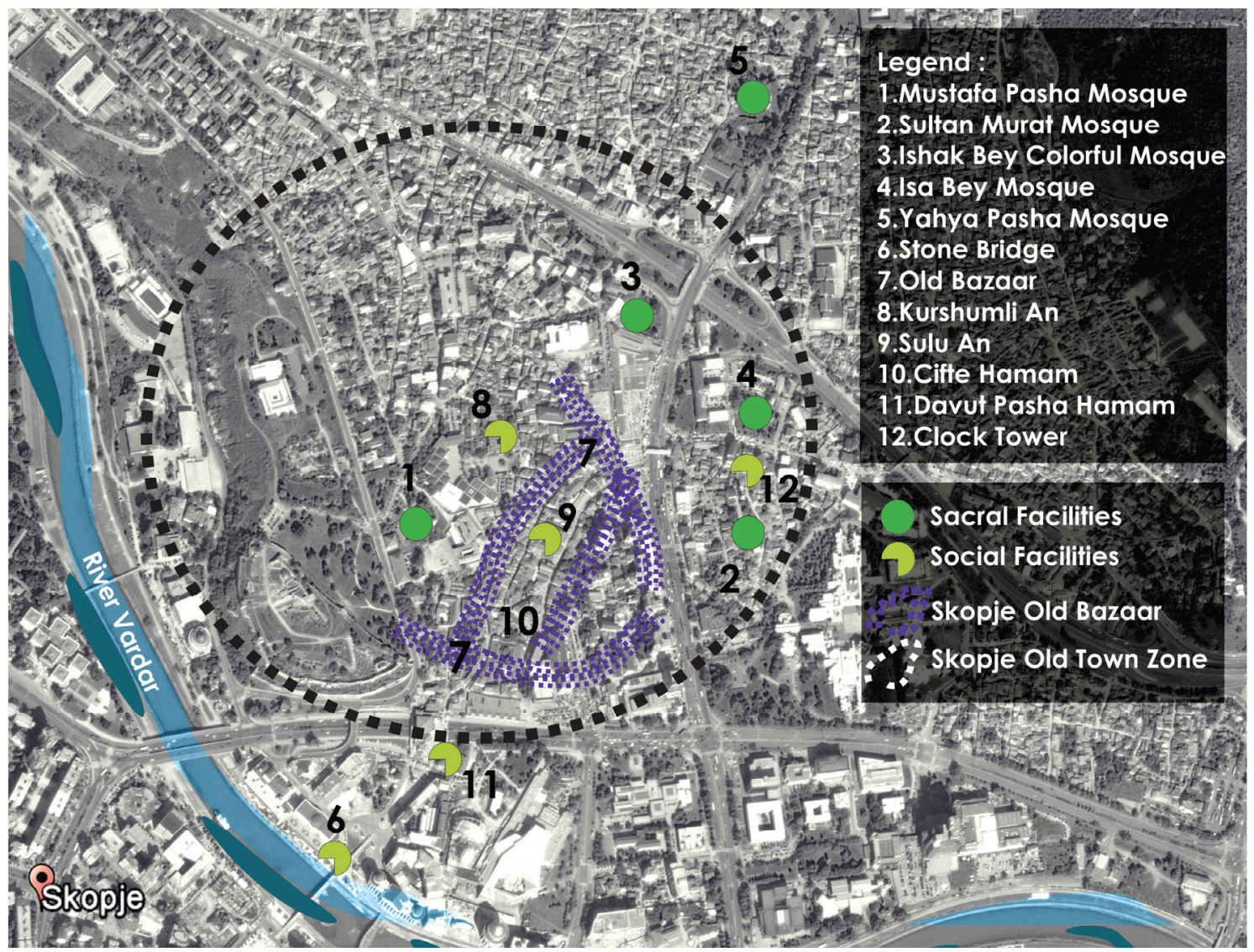

Fig. 4 Old town area with its monumental facilities.

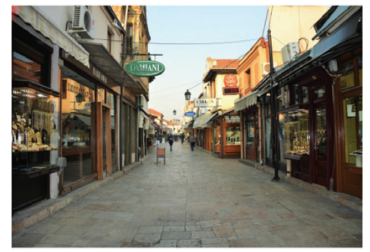

(a)

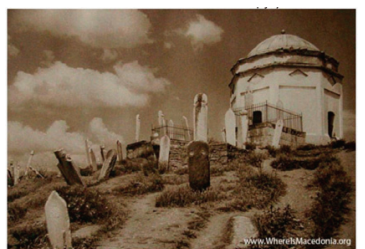

(e)

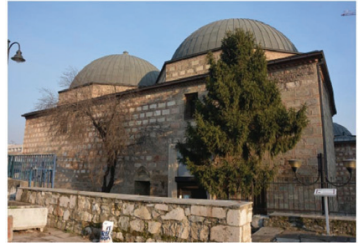

(i)

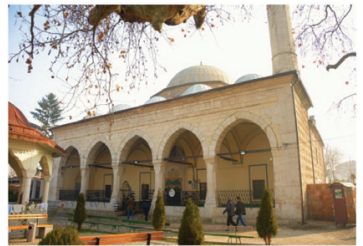

(b)

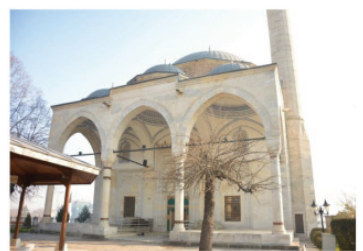

(f)

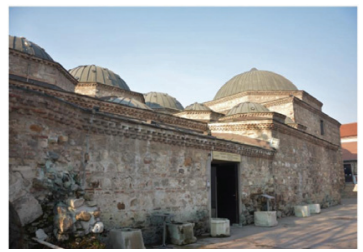

(j)

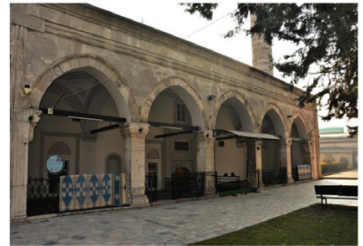

(c)

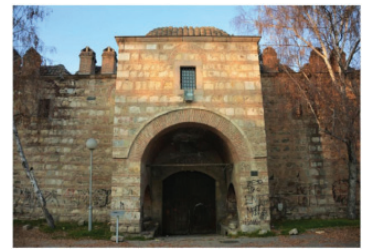

(g)

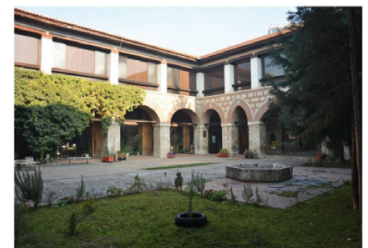

(k)

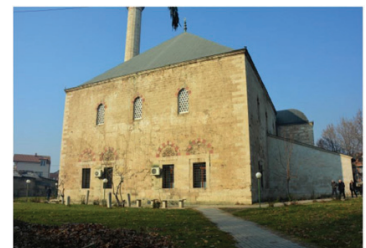

(d)

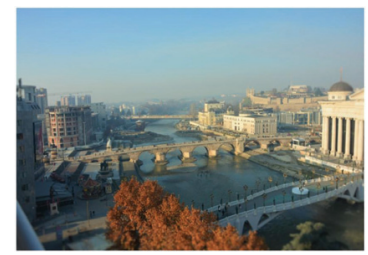

(h)

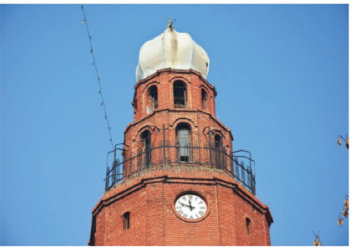

(1)

Fig. 5 Ottoman monumental artifacts in old town-Skopje: (a) Skopje Old Bazaar; (b) Isa Bey Mosque; (c) Alaca Mosque; (d) Yahya Pasha Mosque; (e) Asik Celebi Turbe; (f) Mustafa Pasha Mosque; (g) Old Stone Bridge; (h) Kurshunlu Inn; (i) Daut Pasha Hamam; (j) Cifte Hamam; (k) Suli An; (l) Clock Tower. 
covered with lead. It is built from carved limestone, with horizontally ordered bricks. Facades, at its upper part, end with a double row wreaths derived in the form of a zigzag. Later, in order to increase the visibility, premises has been added inside the mosque from the northern and southern side. Before the entrance of the mosque porch, pillars with five smaller domes have been located [3].

\subsubsection{Alaca Mosque in Skopje}

This mosque (Fig. 5c) has been built by the famous ruler of Skopje-Ishak Bey. The mosque has been named by the inscripted colorful tiles (Aladja), which have been preserved until 1689, and today there are still tiles on the turbe behind the mosque, which have been used to decorated the outer walls. By its architecture and dimensions, mosque building is modest but interesting because of its massive wooden door on the west side, on which shallow carving are performed in various oriental patterns. From the secular buildings in the city of Skopje, which were built simultaneously with the mosques, only six-sided shrine (türbe) from this mosque, covered with lead and nicely staged dome, have been preserved [3].

\subsubsection{Yahya Pasha Mosque in Skopje}

Yahya Pasha Mosque (Fig. 5d) in Skopje was built in 1504. Five hundred years ago, the mosque has been struck by lightning. Over the simple internal square spaciousness rises high dome rib separated. The interior aeshtetic impression is enriched by beautifully-made decorations on the revetment of the walls (in Turkish: mimbar mihrab) using marble. The main entrance portal is framed by marble gladed boards, and over the massive door, carving is carved in marble table stalactites. Pendant, symmetrically arranges according to their dimensions. Wall paintings, left and right above the vertical portal porch, walled two marble mihrab, which in the summer months were used to perform religious rites. From its monumental structure, elegant porch on the west side rests high in form circular roller marble columns, completed with capitals and pointed arches. The minaret of Yahya Pasha Mosque is $50 \mathrm{~m}$ high - the highest of all other mosques in Skopje. The top of the minaret is made of gold half moon and star. Tombstones and turbe (shrine) are preserved in the fenced yard [3].

\subsubsection{Asik Celebi Turbe in Skopje}

On Hill Gazi Baba in Skopje, turbe (Fig. 5e) has been raised lonely, in which was buried Asik Celebi, Gazi Baba and Mehmed Ali El Nata. The Gazi Baba Turbe is closed octagonal building with arch. It is built of brick, and its exterior is plastered. During the 1963 earthquake, the object has been severly damaged, and with the passage of time, turbe has been completely ruined and only few remains can be seen today. Yet, for some, this location today represents a holy and mystical place [3].

\subsubsection{Mustafa Pasha Mosque in Skopje}

Mustafa Pasha Mosque (Fig. 5f) has been erected in 1492 by the ruler of Skopje Mustafa Pasha. The mosque has a fairly simplified square room covered with dome on trompi. In the interior of the mosque, the mihrab is in the middle of the southern-east side and the porch sets on four marble pillars with three smaller domes. The facades of the mosque were built with alternating rows of well-formed stone and two rows of brick. The minaret has been built of well-formed limestone, slightly more white than the limestone used for the mosque. Enlarged part of the minaret is made of marble and decorated with ornaments. The fenced panels are ornamented with round and six lobe rosettes [3].

\subsubsection{Stone Bridge in Skopje}

In Skopje city center, on the river of Vardar, exists the monumental Stone Bridge (Fig. 5g), which today connects the old and new part of the city. According to Turkish sources, the Bridge has been built in the second half of the $15 \mathrm{~h}$ century, during the rule of Sultan Mehmed II. Stone Bridge in Skopje Macedonia is one of the greatest monuments of this kind, built from well-formed stone blocks while his massive construction relies on power poles interconnected with 
semicircular arches [4].

2.3.7 Kurshumli An in Skopje

Kursumli An (Fig. 5h), during its existence has changed its function. At first, it has been an ann (inn) until 1787, when it was turned into a prison. From 1904 to 1912, it was served again as inn. It acts imposing and impressive with the decorative walls and numerous small domes in the form of pyramids with mild issued sides that have been covered with lead. Above the front door, it is released porch arched roof. Many square stone pillars are connected with arches on the ground floor and first floor, creating an intimate setting with yard and fountain within [4].

\subsubsection{Daut Pasha Hamam in Skopje}

The year for construction of the monument is not known but is thought to be the work of Daut Pasha, who has built it in the second half of the 15th century, between 1489 to 1497 . Hammam basically takes the form of a rectangle with minor extensions toward north and south. Its entrance has been from the east, west and north. Over the western part of the building are dominating two large domes, and the rest is covered by 11 unsymmetrical placed and unequal domes, erected on trompi and on low polygonal "tamburi". The interior of the rooms is illuminated by the star open domes covered with glass. Today, Daut Pasha Hamam (Fig. 5i) is used as an art gallery [4].

\subsubsection{Cifte Hamam in Skopje}

In the middle of the 15th century was built Chifte Hamam (Fig. 5j), the second largest hamam during the Turkish Rule in Skopje. The name of Cifte Hamam (double bath) becomes from the two divided parts with separate entrances for men and women of the building. Cifte Hamam today is used as an art gallery and within it is located part of the exhibition from the National Gallery of Macedonia [4].

\subsubsection{Suli An in Skopje}

In the old Skopje Bazaar, near Cifte Hamam was built Suli An (Fig. 5k). The An (Inn) has been located facing the main entrance to River Serava, near which today passes the major road that borders with the
Bazaar. Suli An has been built by Isaac Bay, in the first half of the 15th century, together with the facilities of Murat Pasa Mosque and Cifte Hamam, which have been linked to the Bazaar. The An makes an urban whole which is characteristic for older urban concepts. Considering architectural solution, it is similar to Kursumli An, and it can be said that it belonged to the group of Caravan Saray. The building has a ground floor and the first floor is made with massive walls and arches. Suli An is built of stone and brick, and the appearance of the original roof structure is not known. The An has been reconstructed in 1972 and today in this place are located the Museum of the Old Bazaar and the Skopje Faculty of Arts [4].

\subsubsection{Clock Tower in Skopje}

In the yard north of Hjunkjar Mosque of Sultan Murat II, rises six-sided Clock Tower (Fig. 51), that has been erected in the middle of the 16th century (1566 1572) in Skopje.

The travelers Evliya Çelebi, Haji Kalfa, et al. mention the Clock Tower in their writings that it has been basically hexagonal, and that its upper part has been a wooden construction. After the fire of 1689 , the tower has suffered of damages. In 1904, the wooden construction of the upper part has been replaced with a solid material and mounted a new clock mechanism, which measured the time until recently [1].

\section{Case Study 2: Ohrid}

The Ohrid traditional architecture has "important place in the cultural heritage" of the city. The syntagma of Ohrid traditional architecture refers to the style of building family houses which has been developed in the 18th and 19th centuries during the Ottoman reign. Whitewashed houses, constructed between the 17th and 19th centuries, are located in a place that ensured each one has a view of the lake and sunlight (Fig. 6). There are many examples of Ohrid traditional architecture style of building within the town walls (Fig. 7), including the newly-built houses. 


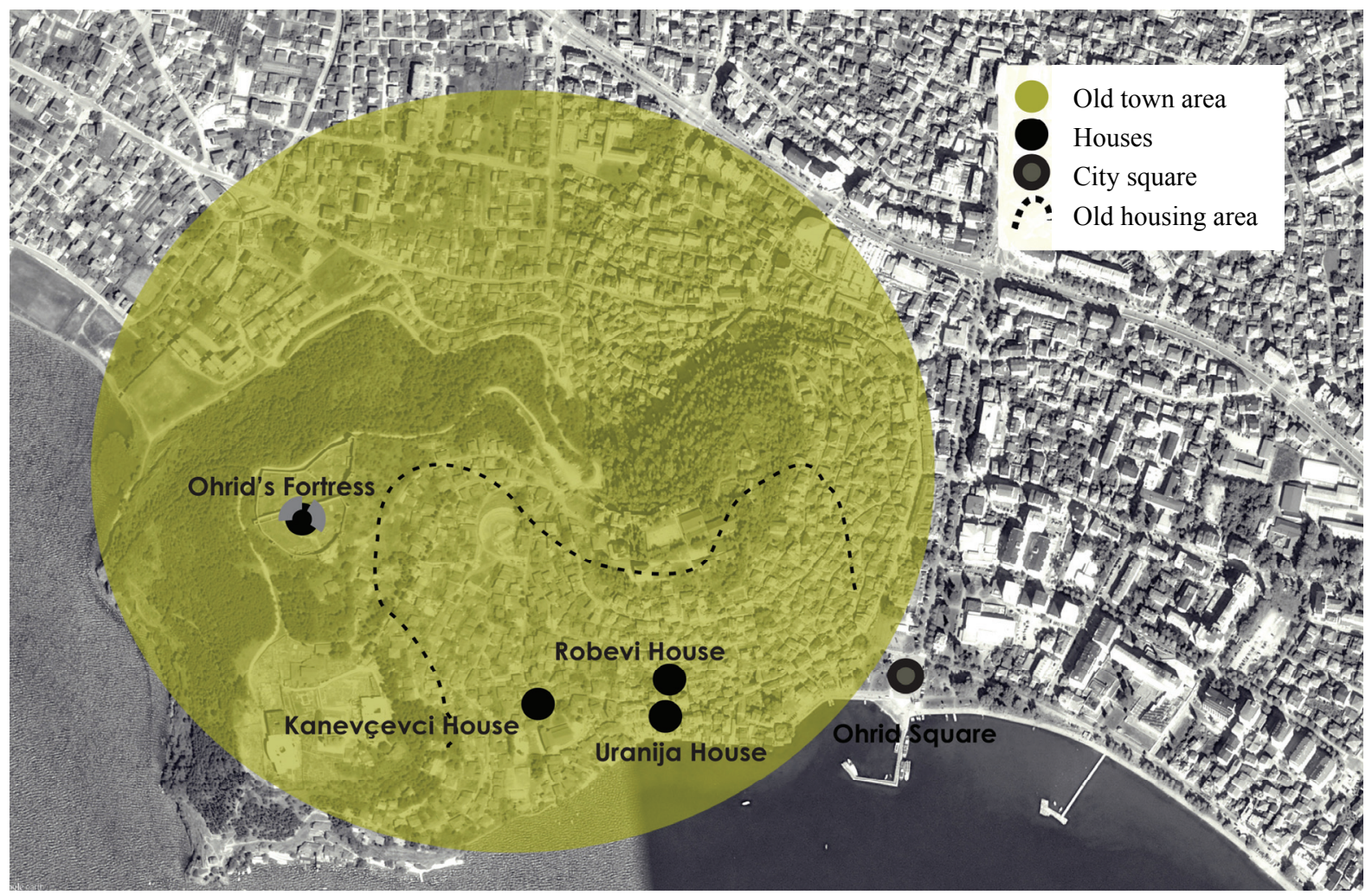

Fig. 6 Ohrid old town area.

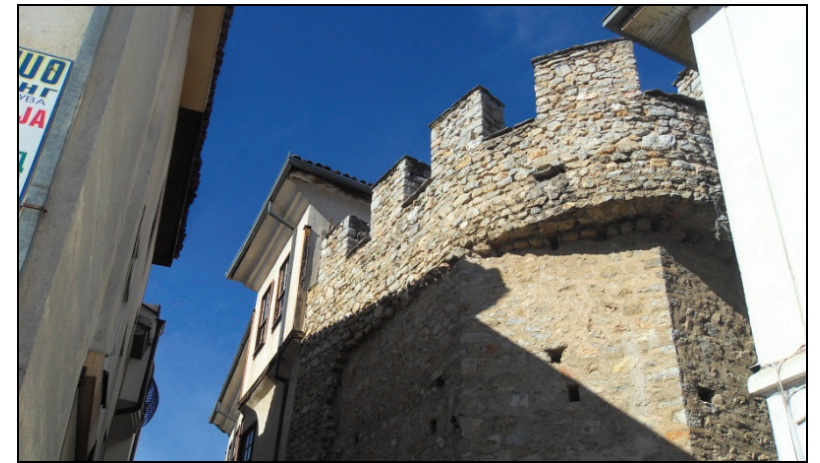

Fig. 7 Old town walls in Ohrid.

Characteristics of this city are also the so-called streets - dark tunnels covered with the upper floors of the houses that were enlarging upward.

A number of early 19th century survived houses in Ohrid, generally two to three storeys with a stone ground floor and upper floors made of wood. They are usually colored white and characterized by boldly arranged facades supported by consoles, wooden eaves and several additional details. These houses are characterized by numerous windows, wide porches and belvederes. Due to local climate, terrain and geography, houses have been placed close to each other and constructed to face Lake Ohrid [5].

The master builders of Ohrid traditional houses, self-taught bricklayers from the region of Debar, have created genuine and wonderful style of building characterized by the houses with upper floors more spacious than the ground floor. They have managed to do that by using light wooden skeleton construction, called bondruk set on the stone built base of the ground floor. The white walls are in strong contrast to the dark wooden window frames which are another elements of so special and beautiful appearance of Ohrid traditional houses. These houses are original and do not have a determined typification, but the space organization is common for all of the houses. On the first floor has lived the family. The upper rooms have been representative and wealthily decorated. They are the largest and have the most beautiful view towards the lake. Some of the houses have had a special room with the most beautiful view called belvedere [4]. 


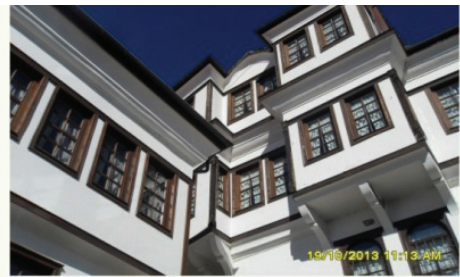

(a)

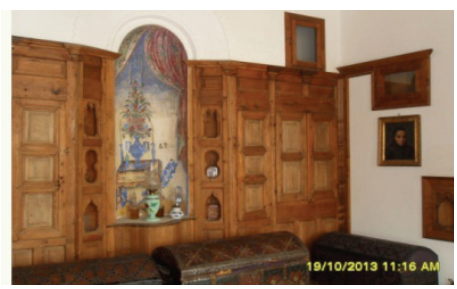

(d)

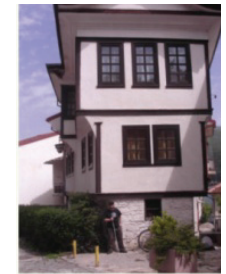

(b)

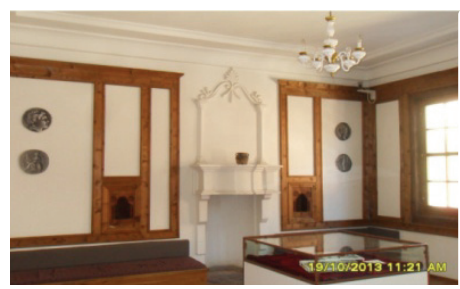

(e)

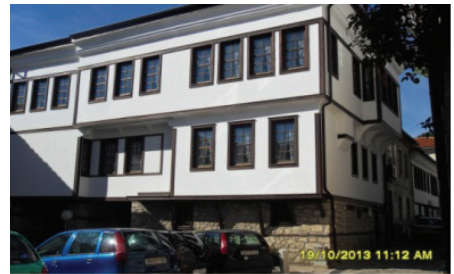

(c)

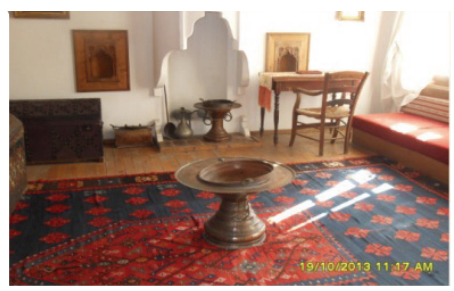

(f)

Fig. 8 Traditional Ottoman houses in Ohrid: (a) Robevi House in Ohrid; (b) Kanevcevci House in Ohrid; (c) Uranija House in Ohrid; (d) Robevi House in interior; (e) Robevi House in interior; (f) Robevi House in interior.

\subsection{The Robevi House}

The peak of the Ohrid traditional architecture certainly is Kukata na Robevci-the House of the Robev family (Figs. 8a, 8d-8f). The building of the first Robevi House has been finished in 1827 and it is a traditional Ottoman Turkish house. The House has been divided in two parts: left and right. The House has been protected as a cultural-historic museum of the Macedonia since the Second World War ended. The last reconstruction of this marvelous building has been applied in the 1990s. Currently, it serves as an exposition space for the archaeological treasures of Macedonia on the first floor. The second floor is a memorial part dedicated to the Robevi family and the third floor functions as a residence. The base of Robevi House is smaller than the upper floors. That is what makes it unique [5].

\subsection{The Kanevcevci House}

Another beautiful example of the Ohrid traditional architecture is Kukata na Kanevcevci-the House of the Kanevce family (Fig. 8b). This house of modest size stands near the marvelous 11th century Church of Santa Sophia. It has been built on the irregular basis with the frontal facade on the narrowest side.

\subsection{The Uranija House}

Uranija House (Fig. 8c) is another well-known building of the Ohrid traditional architecture. It stands very near the House of the Robev family. It houses the Ethnology Department of the National Museum.

\section{Conclusions}

The Ottoman architecture in Skopje is more focused on public and sacral facilities while Ohrid tends toward residential architecture.

The rich Ottoman traditions that has been inherited by the Ottoman ancestors should be a source for inspiring the architects in establishing the guiding principles for new building in the traditional districts with Ottoman heritage in Skopje and Ohrid. By submitting the researched topics and analysis of the Ottoman architecture in Macedonia, it is expected to attract more tourists with hope to put Macedonia (in this case the cities of Skopje and Ohrid) in the world tourist destination map. In this manner, the cultural continuity for achieving the sustainable development would have been attained in the long run.

\section{References}

[1] Bogojevic, L. K., ed. 2008. Ottoman Architecture in 
Skopje. Istanbul: Enka Publishers.

[2] General Directorate of State Archives of Republic of Turkey and Republic of Macedonia. 2005. Macedonia Under Ottoman Rule. Istanbul: Düzey Publishers.

[3] Nikolovski, A., Kjornakov, D., and Balabanov, K. M. 1971. Monuments of Culture in Macedonia. Skopje: Misla Publishers.
[4] Ayverdi, H. E., and Yüksel, A. 1981. Ottoman Monumental Architecture in Yugoslavia. 3rd ed. İstanbul: Istanbul Conquest Society.

[5] Eyice, S. 2006. "Historical Monument from Ottoman Period." In Proceedings of the 22nd Congress of L'Union Européenne des Arabisants et Islamisants, 137-45. (in Turkish) 